\title{
An application of the performance-evaluation model for e-learning quality in higher education
}

\author{
Martínez-Caro, Eva \\ Department of Business Management, School of Industrial Engineering, Universidad \\ Politécnica de Cartagena, Cartagena, Spain
}

School of Industrial Engineering, C/ Doctor Fleming s/n, 30202 Cartagena (Spain)

Cegarra-Navarro, Juan Gabriel

Department of Business Management, Faculty of Business, Universidad Politécnica de Cartagena, Cartagena, Spain

Cepeda-Carrión, Gabriel

Management and Marketing Department, University of Seville, Spain

\begin{abstract}
The demand for e-learning in higher education is rising, competition is increasing, and universities are investing significant resources towards improving the quality of their elearning offerings. Thus, effective quality measures for e-learning are urgently required. With the aim of following the total quality management practices of raising students' satisfaction and continuous improvement, a performance-evaluation model was applied in a sample of business students. The application of this model was useful for selecting the quality items that most urgently require improvement to achieve student satisfaction and for identifying items of surplus resource investment, thereby helping to provide the means to minimize resource wastage. This way, an effective and efficient improvement plan to enhance the efficient use of resources in e-learning and to meet an adequate level of quality was established.
\end{abstract}

Keywords: e-learning quality; performance-evaluation model; student satisfaction; higher education

Eva Martínez-Caro is associate professor of operation management in the School of Industrial Engineering, Universidad Politécnica Cartagena (Spain). She received her PhD degree in business management in 2005. From 2000 until 2005, she served as the Head of the Virtual Classroom of that University. Her current research interests include virtual learning environments, knowledge management, and educational technology management.

Juan Gabriel Cegarra-Navarro is associate professor of Business Management in the Faculty of Business, Universidad Politécnica Cartagena. He is a Doctor in Business Administration and Master in marketing and communications. His research is on the use of knowledge management to help small and medium businesses to become more competitive. During the last few years he has also been dedicating his time to several research projects on the SME sector (at the European Level) including the congenital learning project.

Gabriel Cepeda-Carrión is associate professor in Management and Marketing Department at University of Seville. His main research topics include knowledge management, absorptive capacity, dynamic capabilities and organizational learning and unlearning. He also is an expert in qualitative (case study research) and quantitative (SEM and PLS) methods in management research. His research is published in several top ranked journals. He has developed professional projects about knowledge management in industries such as: banking, health care and professional sport. 


\section{An application of the performance-evaluation model for e-learning quality in higher education}

\begin{abstract}
The demand for e-learning in higher education is rising, competition is increasing, and universities are investing significant resources towards improving the quality of their elearning offerings. Thus, effective quality measures for e-learning are urgently required. With the aim of following the total quality management practices of raising students' satisfaction and continuous improvement, a performance-evaluation model was applied in a sample of business students. The application of this model was useful for selecting the quality items that most urgently require improvement to achieve student satisfaction and for identifying items of surplus resource investment, thereby helping to provide the means to minimize resource wastage. This way, an effective and efficient improvement plan to enhance the efficient use of resources in e-learning and to meet an adequate level of quality was established.
\end{abstract}

Keywords: e-learning quality; performance-evaluation model; student satisfaction; higher education

\section{Introduction}

The subject of quality in higher education has received increasing attention. This study agrees with Ruben (1995) that generally speaking, it is a service industry, one that every day is more and more exposed to globalisation processes (O’Neil and Palmer, 2004), and increasingly intense competition and expectations from stakeholders. Never before have they had to focus on asking what society values in the skills and abilities of their graduates, nor have they been concerned with asking their students how they feel about their educational "experiences" (Ford, 1999). As a consequence, universities and colleges are placing increasing emphasis on improving the quality of their educational services (Kuo and Ye, 2009). 
Service quality is defined as the degree to which an event or experience meets an individual's needs or expectations. How satisfied the customers are on important service elements determines the level of service quality (Hung et al, 2003). As the education sector has transformed itself from a teaching-orientated to a customerorientated model, an educational institute can be seen as a provider of products and services to customers, namely, its students (Kuo and Ye, 2009). Thus, in order to attract students, serve their needs, and retain them, higher education providers are actively involved in understanding the students' expectations and perceptions of service quality (Nadiri at al., 2009).

Because the levels of service quality and customer satisfaction are of the greatest Con formato: Color de fuente: Automático importance, universities are investing significant resources towards improved service quality. Moreover, with the availability of new technology and the Internet, universities are increasingly finding innovative ways of teaching. During the last few years, universities have been experimenting with the use of e-learning in order to look at what new technology can offer to both their existing students and potential 'new' students (Hodgson, 2002). E-learning can be viewed as synonymous with web-based learning, online learning, internet-based training, or virtual learning (Khan, 2001). It can be considered as a teaching-learning process supported by information and communication technologies (ICT), in which it is not necessary to have a physical meeting of teachers and students, and whose objective is to facilitate a flexible (at any time and place), interactive, and student-centred learning (Martínez-Caro, 2011).

The use of e-learning as a teaching and learning tool is now rapidly expanding into education, with thousands of courses offered by educational institutions. The major forces driving its popularity are: (1) the emergence of a worldwide communication network, with powerful computer technologies leading to a revolution in all sectors, 
including education; (2) the perception of e-learning as a solution to the cost and quality problems of universities (Selim, 2007); and (3) profound changes in the ways in which we work and live, which are claiming a new concept of education for those who have irregular working schedules and both family and employment commitments (Shen et al., 2007; Marks, et al., 2005). University students are becoming more diverse and the demand for e-learning courses is going up (Papp, 2000). Competition is increasing and it is not surprising that universities are trying to differentiate their 'product' by infusing quality into their e-learning offerings (Aggarwal and Adlakha, 2006).

The increasing use of alternative teaching methods such as e-learning is clearly changing the traditional understanding of educative activities. Thus, effective servicequality measures for e-learning are urgently required. From a total quality management (TQM) approach, raising students' satisfaction and continuous improvement should be the two main areas of focus (Yang, 2003a). Student satisfaction in the classroom is an inherently desirable goal and a benefit of teaching. There is a considerable volume of research related to the benefits of satisfaction in higher education. For example, satisfaction has been linked to student performance (Bean and Russell, 1986; Marks et al.; 2005, Martínez-Caro; 2011), retention (Astin, 1993; Tinto, 1993; DeShields et al., 2005), class attendance (Spady, 1979; Aitken, 1982; Bean, 1985), or student engagement (Kuh, 2003; Zhao and Kuh, 2004; Coates, 2005). Moreover, student satisfaction is often used to assess educational quality (e.g. Cheng, 1990, Ramsden, 1991; Nadiri et al., 1994; Lawrence and McCollough, 2004). Satisfaction is particularly important when considering e-learning environments, because if students are not satisfied with the online course experience they could opt out of e-learning courses or transfer to other institutions (Arbaugh and Benbunan- 
Fich, 2007). Several models are available to measure student satisfaction, each one with its own advantages and disadvantages (Chen, 2009). However, the most pressing disadvantage of these models is their inability to provide accurate priorities for improvement (Chen et al., 2006; Yang, 2003b). O’Neill and Palmer (2004) argue that, while much time is taken up discussing the psychometric performance of such tools, their real value to the higher education sector rests on their ability to pinpoint service failures and to direct continuous quality improvement efforts that are of demonstrated importance to students.

As a consequence, the purpose of this particular study was to select and apply the most adequate model for the improvement of e-learning quality in higher education. In particular, this was accomplished through an assessment of the perceptions of a sample of business students at one higher education institution by using the performance-evaluation model.

\section{Measuring quality in higher education}

A challenge facing practitioners in teaching is the identification and implementation of the most appropriate measurement tools to gain a better understanding of the quality issues that impact on the experiences of students (O’Neil and Palmer, 2004). In the absence of objective measures, higher education providers must rely on the students' perceptions of quality to identify the strengths and weaknesses of educational programs, and to conceive appropriate improvement strategies.

Universities have traditionally employed qualitative or quantitative methods to Con formato: Color de fuente: Automático measure students' perceptions of quality, such as interviews, focus groups, or observation research. Many models have been adapted in higher education from quality improvement methodologies used in the industry: Total Quality Management 
(TQM), Quality Function Deployment (QFD), Six Sigma, ISO 9001, the Malcolm Baldrige National Quality Award or the EFQM Model. Other techniques have been created ad hoc for higher education (e.g. College Student Satisfaction Questionnaire (CSSQ), Course Perception Questionnaire (CPQ), Student evaluation of teaching (SET) instruments). While traditional research on quality education has borrowed heavily from the management discipline and job satisfaction theory, current researchers shift their focus to customer satisfaction theories from the service marketing discipline (Franklin and Shemwell, 1995). Traditional questionnaires reduce student satisfaction to a static outcome of a uni-dimensional process whereas researchers in marketing have a different perspective: satisfaction is a process in which student will experience a beginning expectations state and an ending performance state (Oliver, 1993). As a consequence of this dynamic nature of satisfaction, the most appropriate method for assessing student satisfaction is through an expectation-disconfirmation process (Franklin and Shemwell, 1995). The disconfirmation approaches have become pre-eminent in the sector (Chen, 2009). An often used model most often utilized has been SERVQUAL, developed by Parasuraman et al. (1985, 1988). This instrument performs quality evaluation by comparing the customers' expectations with their perception of the organisation's service performance. SERVQUAL conceptualises service quality through five factors, namely, tangibles, reliability, responsiveness, assurance, and empathy.

While SERVQUAL is widely recognised for its various adaptations for different industries, including the educational context, it has also attracted considerable criticism. Ford (1999) pointed out the following: (1) the potential inappropriateness of the five dimensions of choice criteria used by SERVQUAL; (2) the inability of expectations to remain constant over time; and (3) the lack of prior knowledge and 
experience with university education and the unrealistic expectations of incoming university students. As a result of these criticisms, an alternative method of assessing service quality was needed. This led to the development and application of a more direct form of measurement technique, known as SERVPERF (Cronin and Taylor, 1992).

The SERVPERF technique makes use of the original SERVQUAL scale items and Con formato: Color de fuente: Automático requires the customer to rate a provider's performance. However, it does not seek to estimate difference scores, but requires the consumer to rate only the performance of a particular service encounter. It has been argued that a performance-only measure explains more of the variance in an overall measure of service quality than does the SERVQUAL instrument (Cronin and Taylor, 1994). However, although taking a single measure of service performance is seen to circumvent some of the problems raised regarding SERVQUAL, it is felt that from an operational point of view much useful information is lost when performance-only measures are taken (O'Neill and Palmer, 2004).

Martilla and James (1997) developed the importance-performance analysis (IPA) as a Con formato: Color de fuente: Automático tool to develop marketing strategies. Like SERVPERF, IPA is described as an absolute measure of performance, aimed at identifying the underlying importance ascribed by students to the various quality criteria under assessment. An attractive feature of IPA is that the results may be graphically displayed on an easily interpreted two-dimensional grid (Martilla and James, 1997), which demonstrates the mean of importance and performance ratings for attributes used to assess the quality of a particular service (Ford, 1999). The importance-performance grid is interpreted through four quadrants: (a) concentrate here: reflecting that certain aspects of the 
organisation, which are important for customers, are not performing to their full service potential; (b) keep up the good work: reflecting a level of optimal performance; (c) low priority: reflecting a low level in a feature's performance but customers do not perceive this feature to be very important; and (d) possible overkill: reflecting a high level in a feature's performance but customers do not perceive this feature to be very important. Importance is viewed as a reflection by consumers of the relative value of the various quality attributes. It is this additional information that makes the technique more suited to the task of directing improvement based on what is deemed by consumers as most important (O’Neill and Palmer, 2004).

Over the years, many different IPA variations have emerged. For example, Yang (2003a) used the TQM practices of raising customers' satisfaction and continuous improvement as the bases to propose the importance-satisfaction (I-S) model. The purpose of the model is to identify the actual requirements of customers and the actual level of customers' satisfaction. It is then possible to identify which quality attributes require steps to be taken to ensure improvement. As with the IPA, the I-S allows results to be graphically displayed on a two-dimensional grid: the degreeof importance of a given quality attribute and the satisfaction level of that quality attribute. Four areas are defined (Yang, 2003b): (1) the excellent area: companies should endeavour to maintain good performance with respect to the items in this area; (2) the to-be-improved area: companies should focus on the items in this area with a view to making improvements immediately; (3) the surplus area: the attributes listed in this area are not very important for customers, but they are quite satisfied with them; and (4) the care-free area: customers perceive lowers satisfaction levels but they also feel that these items are less important. 
It must be borne in mind that the basic issue in improving service quality performance is determining the priorities for critical service elements and drafting the improvement plan to effectively and efficiently enhance all the service quality levels (Hung et al., 2003). Despite the advantages of the I-S model, it is unable to suggest improvement priorities. To overcome this lack, this research proposes the use of an alternative model: the performance-evaluation model.

\section{Performance-evaluation model}

Although I-S analysis overcomes the criticisms of the SERVQUAL and SERVPERF models and, unlike IPA, reflects specifically the TQM principle of raising customer Con formato: Color de fuente: Automático satisfaction, some shortcomings still exist in this model (Chen, 2009). First, the application of the I-S model is limited to questionnaires based on a 7-point scale. Second, the attributes located in the 'surplus area' are imply an overinvestment. According to the I-S model, organisations do not need to take any particular action with respect to such attributes. This approach does not square with a reality in most organisations because resources are limited and, consequently, it is vital that resources are not overinvested in wasteful areas. Third, the attributes located in the 'to-be-improved area' require improvement; however, the I-S model does not suggest what item should be given priority with respect to improvement strategies. Fourth, when the quality attributes lie on the borderline between two areas it is unclear whether these attributes should be improved or not. With the aim of addressing these shortcomings, Chen (2009) proposes a modified I-S model, called the PerformanceEvaluation model. In this model, the performance matrix is divided into three performance zones (Figure 1) that represent the effectiveness of various systemimprovement items. The first is Zone A, or the insufficient resources zone. The quality attributes that fall into the Zone A have greater importance than satisfaction; 
thus, more resources must be invested in these attributes to improve satisfaction. The second is Zone B, or the misspent resources zone. The quality attributes that fall into Zone B have less importance than satisfaction; thus, the investment of resources in these items should be decreased to prevent waste. The third is Zone APCZ, or the appropriate performance control zone. The investment of resources in the quality attributes that fall into this zone must be maintained. The three areas are limited by two lines, the performance upper control limit (PUCL) and the performance lower control limit (PLCL). Between these two lines is an oblique line representing the performance-control centre limit (PCCL). These lines are established according to the coordinates that enable objective diagnosis and judgment of the required improvements to be performed. Organisations should seek to improve only those Con formato: Color de fuente: Automático items that are located outside the control lines. Following Chen (2009), PUCL and PLCL are defined as $+3 \sigma$ and $-3 \sigma$, respectively, with $\sigma$ being the standard deviation or Con formato: Color de fuente: Automático the performance-control matrix.

<Figure 1. Performance-control zone of performance matrix.>

Con formato: Color de fuente: Automático

This performance-control matrix is expressed in terms of a performance-control matrix index (PCMI), which is defined as the index of satisfaction minus the index of importance. In turn, the indices of importance and of satisfaction are defined as follows:

Con formato: Color de fuente: Automático

$$
\begin{gathered}
P_{I}=\frac{\mu_{I}-\min }{R} \\
P_{S}=\frac{\mu_{S}-\min }{R}
\end{gathered}
$$

Código de campo cambiado

in which

$\mathrm{P}_{\mathrm{I}}=$ index of importance,

Con formato: Color de fuente: Automático 


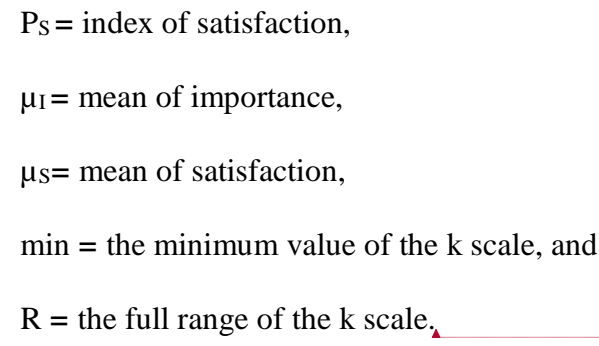

If the PCMI has a positive value, this indicates that importance is less than satisfaction and that fewer resources should be invested to prevent waste. Conversely, if the PCMI has a negative value, this demonstrates that importance is greater than satisfaction and that more resources should be invested to improve satisfaction.

The additional and very useful contribution of this performance-evaluation model approach is that the LTB (larger the better) model is adopted, in which a large loss function value indicates improvement priority. That is, a greater PCMI indicates that an item should be given priority with respect to improvement strategies.

\section{Empirical analysis}

\section{Questionnaire design}

A questionnaire of student satisfaction in e-learning was developed based on a review of the literature (e.g., Arbaugh, 2000; Stokes, 2001; Selim, 2005; Wang, 2003; Agarwal and Day, 1998; Motiwalla and Tello, 2000; Marks et al., 2005; Ozkan and Koseler, 2009; McGorry, 2003). Most researchers agree that the main factors affecting student satisfaction are the following: (1) teacher-student interaction, (2) student-student interaction, (3) learning contents, and (4) system flexibility and support. Traditionally, distance education has been criticized because of the lack of interaction between teacher and students and between students. During the last few years, however, with the introduction of ICT, the number of tools to promote the 
interaction between the participants of an online course has increased greatly. Thus, an increasing number of studies suggest that interaction, whether it is between participants and/or between participants and the teacher, is one of the strongest predictors of positive outcomes in e-learning (Arbaugh and Benbunan-Fich, 2007; Flottemesch, 2000; Palloff and Pratt, 2001; Swan, 2002; Zhao et al., 2005).

In a traditional face-to-face classroom, a teacher-centred model is frequently adopted. Students are taught as if they were passive recipients of knowledge and had little engagement in the instructional tasks. In this approach the students have no incentive to construct their own knowledge and little motivation to retain information or transfer its use to novel situations (Berge and Collins, 1995). E-learning instruction is learner-centred rather than teacher-centred, and knowledge is viewed as a social construct, facilitated by peer interaction, evaluation, and cooperation. Therefore, the role of the teacher changes from transferring knowledge to students (the "sage on the stage") to being a facilitator in the students' construction of their own knowledge (the "guide on the side") (Benbunan-Fich and Hiltz, 2003). Learner-teacher interactions contribute to that objective by establishing an environment that encourages learners to understand the content better (Su et al., 2005). Harasim et al. (1995) reported that elearning allows an increased interaction between the teacher and the students that could be even better than the interactivity achieved in the traditional setting. In addition, e-learning allows a more equitable distribution of the teacher's attention among the students (Hartman et al., 1995). Furthermore, students who are shy or uncomfortable about participating in class discussions often no longer feel that way in online forums (Owston, 1997).

On the other hand, the interaction between students in a course is well documented and considered a valuable experience and learning resource (e.g., Rovai, 2002; Pallof 
and Pratt, 2001; Benbunan-Fich and Hiltz, 2003; Vrasidas and S.M. McIsaac, 1999; Arbaugh, 2004) and a critical component of quality education (Anderson, 2001).

Learning is most successful when small groups of students share and discuss information (Arbaugh and Benbunan-Fich, 2007). The students may learn as much, or more, from each other as they do from the professor and the textbook (Brower, 2003). When students work with peers instead of alone (or just with the teacher), anxiety and uncertainty are reduced as learners communicate with their peers and find their way together through complex or new tasks (Harasim, 1995). In some cases, students have even expressed a preference for online dialogue over traditional classroom discussion because they can participate more fully and can reflect upon the comments and responses of other students before sharing their own (Clark, 2001).

The process of creating an effective learning experience involves effective configuration of curriculum content and pedagogic content, among other factors (Biggs, 1999). Content quality in e-learning depends on how well the learning environment is designed and managed. For example, students highlighted the importance of the following aspects relative to content: good organisation, effective presentation, right length, usefulness, ease in understanding, interactiveness, and upto-datedness (Holsapple and Lee-Post, 2006; Shee and Wang, 2008). Additionally, students state that clear examples, illustrations, and given additional resources gain their attention, and positively influence their satisfaction (Ozkan and Koseler, 2009). In that respect, to offer a high value in e-learning, plain text content must be complemented with other new media, such as multimedia presentations, audios, videos, or simulations (Marks et al., 2005).

Prior research has stressed that the main advantages of e-learning are related to the flexibility and convenience that this type of educational delivery system provides to 
students (Selim, 2007; Arbaugh, 2002; Choy et al., 2001; Leonard and Guha, 2001). E-learning flexibility can remove time and location barriers, enable students to access information in a self-paced fashion, and reinforce learning (Ellsworth, 1994). Furthermore, e-learning allows some students to combine education with other activities such as work, enabling those who otherwise do not have the opportunity to complete educational programs to do so.

However, it must be taken into account that students in e-learning courses often face technical problems. According to Ngai et al. (2007), it is essential for universities to provide effective technical support to users to encourage them to use their e-learning systems. Several research studies have suggested that the provision of appropriate user technical support is among the most effective methods of ensuring user satisfaction (Mirani and King, 1994). It is also important for the e-learning system to have stability, security, reliability, ease of use, and a well-organized design (Shee and Wang, 2008) because a user-friendly learner interface becomes one of the most critical factors in determining the satisfaction of learners in e-learning (Ozkan and Koseler, 2009).

Table 1 below shows the items used for measuring student satisfaction according to these factors. A double 5-point response scale was used $(1=$ very unsatisfactory and 5 $=$ very satisfied, to measure satisfaction, and $1=$ very unimportant and $5=$ very important, to measure importance).

< Table 1. Factors and items of questionnaire.>

\section{Sample and data collection}

We used a sample of 408 students enrolled in 14 class sections of 6 courses at one university delivered in the e-learning modality over the course of four academic years. 
The courses were in the field of operations and production management at the graduate and postgraduate levels . Using students from multiple courses provided methodological benefits such as external validity and increased statistical power (Marks et al., 2005). Students completed the questionnaire via the tools provided by the e-learning system which guaranteed the anonymity of the students. Data were collected from 333 students, for a response rate of 81.61 percent.

Students in all courses were supplied with the following resources:

(1) Course information: The instructor placed items such as the course schedule, the syllabus, learning objectives and goals, general instructor information , and/or recommended bibliography.

(2) Access to a resource centre: a shared knowledge base that stores online lectures, articles, case studies, videos, multimedia presentations, graphics, or links to resources relevant to the course.

(3) Asynchronous communication tools were used in all courses, such as e-mail and debate forums. Synchronous tools such as chat were used for some of the courses. These tools were used for the communication between students (e.g., discussion of case studies, collaborative task) and between students and teachers (e.g., teacher follow-up of students, online tutorials).

(4) Assessment tools were used for hand-in of reports, group and individual deliverables for assessment. In some cases, multiple-choice-type examinations and open questions were used as well.

(5) Student tools: These tools allowed students to track their progress and check their grades online. Students could also develop their own personal information pages and share them with their classmates. 


\section{Research results}

The SPSS 15.0 statistical pack was used to analyse the data. Reliability was assessed using Cronbach's alpha. The coefficient alpha for students' satisfaction and for students' importance as well as for each dimension was greater that 0.7 , the commonly accepted lower limit for alpha (Nunnally, 1978), hence the questionnaire had good reliability.

The means for satisfaction and for importance of the twenty items were calculated, and then transformed to $\mathrm{P}_{\mathrm{S}}$ and $\mathrm{P}_{\mathrm{I}}$, respectively. Performance-control matrix indeces and PUCL and PLCL were also calculated (Table 2). Then, the control lines were drawn and the coordinates of $\mathrm{P}_{\mathrm{S}}$ and $\mathrm{P}_{\mathrm{I}}$ were mapped onto the performance-control matrix. The performance-control matrix revealed that items 15 and 18 were outside PLCL and items 3, 8, 10, and 19 were outside PUCL (Figure 2).

Table 2. Performance and Satisfaction Results.

Figure 2. Performance-control matrix.

\section{Discussions}

Universities, as with any organization, have limited resources, and thus must manage these resources in the most efficient way. From a continuous quality improvement point of view, the performance-evaluation model used in this research allows making a prioritization between the items for improvement by classifying them according to their PCMI. This way, a more efficient management of the universities' resources is possible. The results of this study suggest that six areas must be improved in elearning: 
(1) Item 8 , with a PCMI net value of 0.4842 , suggested that this item should be given the highest priority for improvement. This item referred to the efforts made by instructors to encourage interaction with students. The item was located in the performance-control matrix outside PUCL, which implies that instructors should do more to promote student satisfaction. While students considered the instructor's availability, attitude, and level of interaction with them to be adequate, the efforts made by instructors to promote that interaction were not deemed to be enough.

These results suggest that if students take the initiative of contacting the teacher they Con formato: Color de fuente: Automático will have an adequate communication with such teacher, but if the students do not adopt an active role interaction will not take place. The direct implication of this finding is that teachers must be actively engaged with their courses to enable participants to obtain better learning and satisfaction outcomes. To improve effectiveness, Lehman et al. (2001) advise teachers to interact with students in a prescribed manner by providing the theoretical rationale as well as multiple examples of motivation-building and personal-investment enhancements. According to Marks et al. (2005), teachers could seek student involvement in discussion, tell a case story about a subject to aid remembering, use positive reinforcement for successful performance, and ask questions to students.

(2) The second item that needs to be improved is item 3, with a PCMI net value of 0.3251 . This item is related to the encouragement of students to interact with other students. The item was located in the performance-control matrix outside PUCL, suggesting that student-student interaction is not promoted enough. Similar to the previous item, the implication of the finding is that if students take the initiative of Con formato: Color de fuente: Automático contacting their classmates they will have an adequate level of interaction with 
them, but if students do not adopt an active role, interaction will not take place. Some writing on-online learning communities literature suggests that people need encouragement to share information and to learn from each other (Newman and Smith, 1999), hence the course must be structured in a way that encourages student participation amongst themselves (Vrasidas and McIsaac, 1999). To that end, strategies such as requiring students to post discussion comments and assignments for all members of the class to respond to, or encouraging cooperative group work, can be adopted (Benbunan-Fich and Hiltz, 2003).

(3) The third item that needs to be improved is item 19, which refers to the effective management of study time by students, with a PCMI net value of 0.2995 . The item was located in the performance-control matrix outside PUCL, and so more resources must be allocated to help students manage their study time. The anytime-anywhere aspect of e-learning has long been touted as one of its most significant advantages over traditional classrooms, but research shows that students need time to process and contextualize the freedom that this learning involves (Arbaugh, 2004) and to accept that the responsibility for the learning process now falls on them. To help students in this situation, it could be crucial to teach them how to learn online as soon as they start the e-learning experience. Arbaugh (2004) proposes that instructors give new learners focused attention to help them in their transition to online learning. Experienced classmates might also play an important part by sharing their knowledge with the novice students and explaining to them how to manage their study time, as an additional help to the instructors' efforts, in their first e-learning experiences.

(4) The fourth item that needs to be improved is item 18 , which refers to access to technical assistance, with a PCMI net value of 0.2920 . This item was located in 
the performance-control matrix outside PLCL, indicating that there might be an overinvestment in resources allocated to technical assistance, which must be reduced to avoid waste. Contrary to expectations, technical assistance is not so crucial for students. This can be explained by the decrease in the gap between the students' levels of computer experience and the use of Internet in the last few years with the development of higher levels of technological skills (MartínezCaro, 2010). Therefore, technical assistance may no longer be key for students in e-learning, freeing some of these funds to use in other areas where deficiencies are identified.

(5) The fifth item that needs improvements is item 10, with a PCMI net value of 0.2823. This item refers to the facilitation of interaction between students and instructors using a variety of ways. As the item was located in the performancecontrol matrix outside PUCL, it can be supposed that the resources allocated to promote the interaction between instructors and students are not enough and Con formato: Color de fuente: Automático more resources in this area are needed. Challenges such as communication between student and instructor limited to e-mail communication (Zhao et al., 2005) and student time and commitment issues impacting synchronous techniques such as the use of student chats (Sanders \& Mossison-Shetlar, 2001) also pose difficulties in promoting better interactions between students and instructors. Therefore, approaches based on specific communication strategies are not advisable. Instead, the key could be to offer an adequate mix of synchronous (e.g., chats, audio or videoconferences) and asynchronous (e.g., e-mail, discussion boards) communication tools in order to meet the interaction needs of all students.

(6) The last item that needs to be improved is item 15 , which refers to the variety of tools used in student-content interaction, with a PCMI net value of 0.2685 . This 
item, as item 18 above, exceeded the PLCL, indicating that the resources allocated to develop different tools for student-content interaction must be reduced to avoid waste. This finding can be explained by the fact that the media are not as important as the message itself, with some research showing that the positive effects of new media on the learning experience are caused mainly by the Hawthorne - or halo -- effect ${ }^{2}$, rather than by the media per se (Clark, 1985). For example, research shows that including too much unnecessary multimedia elements in instructional material may distract learners and actually decrease learning performance (Bartscha and Cobern, 2003; Mayer et al., 2001). Sun and Chen (2007) consider it expensive to design and develop multimedia instructional material because of their findings to the effect that multimedia content alone does not necessarily result in significant positive learning performance and satisfaction; indeed, they found it ineffective to use highrichness media, such as video conferencing or interactive contents, to promote learning performance for course units with low uncertainty and equivocality, the content of which could be stated clearly in regular text. In conclusion, what is needed is to create an appropriate equilibrium between cost and media in order to help students understand content and to avoid wasting institutional resources.

\section{Conclusions}

At the heart of all quality initiatives there is an emphasis on the use of data to make decisions associated with quality improvements (Wild and Hope, 2003). In this study, the data from students' perceptions of satisfaction and importance were transformed into reccomendations to improve resource investment in e-learning programs in higher education. 
The first contribution of this research is the use of a model to measure quality in elearning that is not focused exclusively on evaluating quality through selected attributes in terms of the students' satisfaction, with the aim of improving those attributes with the lowest levels of satisfaction. Low-quality attributes should not be the only consideration when designing improvement plans. The approach employed is more ambitious because it suggests taking actions to improve the attributes that have low satisfaction levels and are important to students at the same time. Furthermore, the performance-evaluation model employed is a useful tool for selecting quality items that most urgently require improvement to achieve student satisfaction in elearning and for identifying items of surplus resource investment, thereby helping to provide the means to minimize resource wastage. The information gathered through this approach helps in the drafting of an effective and efficient improvement plan to enhance the efficient use of resources in e-learning and to meet an adequate level of quality.

The second contribution is derived from the several implications of the results. An underinvestment was identified in several areas, suggesting the following prioritized improvements: (1) instructors must adopt an active role and make additional efforts to encourage student participation; (2) to allocate resources in teaching students how to learn online and helping them in their transition to e-learning; and (3) Investing more resources to provide different ways to promote teacher-student interaction. On the other hand, the data in this study suggests that there is an overinvestment in Con formato: Color de fuente: Automático Con formato: Color de fuente: Automático providing technical assistance to students and in the development different tools for student-content interaction. Students' skills and needs are changing and institutions must be aware of these changes in order to adapt the allocation of their resources to the actual requirements. In summary, the findings of this study can help colleges and 
schools learn more about how to enhance e-learning quality while simultaneously promoting efficiency in the investment of resources.

Finally, this study is not lacking in limitations. Firstly, although several e-learning courses in different subjects were analyzed, the study was conducted at a single institution. Thus, the findings may not be widely generalizable. Further research is needed with broader samples. Secondly, all courses analyzed in this study were delivered fully online. Classroom-based courses or blended courses were not considered. Hence, it cannot be said that the findings of this study are unique to elearning courses. The performance-evaluation model could be a promising tool for assessing quality in any learning modality. Future research is also needed to address this issue . Furthermore, it could be interesting to compare the findings with those that would be found using more traditional instruments for assessing student satisfaction with instruction. This comparison may help universities to select the appropriate assessment instrument to make the adequate strategic decisions.

\section{References}

Aggarwal, A.K., \& Adlakha, V.G. (2006). Quality Management Applied to WebBased Courses. Total Quality Management, 17(1), 1-19.

Aitken, N.D. (1982). College student performance, satisfaction and retention: Specification and estimation of a structural model. The Journal of Higher Education, 53(1), 32-50.

Anderson, T. (2001). The hidden curriculum in distance education. An update view. Change, 33(6), 28-35.

Arbaugh, J.B. (2000). Virtual Classroom Characteristics and Student Satisfaction with Internet-Based MBA Courses. Journal of Management Education, 24(1), 3254.

Arbaugh, J.B. (2002). Managing the on-line classroom. A study of technological and behavioral characteristics of web-based MBA courses. Journal of High Technology Management Research, 13, 203-223.

Arbaugh, J.B. (2004). Learning to learn online: A study of perceptual changes between multiple online course experiences. Internet and Higher Education, 7, 169-182.

Arbaugh, J.B., \& Benbunan-Fich, R. (2007). The importance of participant interaction in online environments. Decision Support Systems, 43, 853-865. 
Astin, A.W. (1993). What matters in college? Four critical years revisited. San Francisco: Jossey Bass.

Awargal, R., \& Day, E. (1998). The Impact of the Internet on Economic Education. Journal of Economic Education, 29(2), 99-110.

Bartscha, R. A., \& Cobern, K. M. (2003). Effectiveness of PowerPoint presentations in lectures. Computers \&Education, 41, 77-86.

Bean, J. P. (1985). Interaction effects based on class level in an explanatory model of college student dropout syndrome. American Educational Research Journal, 22(1), 35-64.

Bean, J.P., \& Russell K.B. (1986). Untangling the satisfaction-performance relationship for college students. The Journal of Higher Education, 57(4), $393-$ 412.

Benbunan-Fich, R., \& Hiltz, S.R. (2003). Mediators of the effectiveness of online courses. IEEE Transactions on Professional Communication, 46 (4), 298-312.

Berge, Z. \& Collins, M. (1995). Computer-mediated communication and the online classroom in distance learning. Computer-Mediated Communication Magazine, 2(4). Retrieved from http://sunsite.unc.edu/cmc/mag/1995/apr/ berge.html.

Biggs, J. (1999). Teaching for quality learning at university. Buckingham: Open University Press.

Brower, H.H. (2003). On emulating classroom discussion in a distance-delivered OBHR course: Creating an on-line community. Academy of Management Learning and Education, 2 (1), 22-36.

Chen, S.H. (2009). Establishment of a performance-evaluation model for service quality in the banking industry. The Services Industries Journal, 29(2), 235247.

Chen, S-H., Yang, C-C., Shiau, J-Y., \& Wang, H-H. (2006). The development of an employee satisfaction model for higher education. The TQM Magazine, 18(5), 484-500.

Cheng, Y.C. (1990). Conception of school effectiveness and models of school evaluation: A dynamic perspective. Education Journal, 18(1), 47-62.

Choy, S., McNickle, C. \& Clayton, B. Online support for VET clients: expectations and experiences. 2001 AVETRA conference: Research to reality: putting VET research to work, 28-30 March, Adelaide (Australia), 2001.

Clark, L.J. (2001). Web-based teaching: A new educational paradigm. Intercom, 48, 20-23.

Clark, R. (1985). Evidence for confounding in computer-based instruction studies: Analyzing the meta-analyses. Educational Communication and Technology Journal, 33(4), 249-262.

Cronin, J.J.Jr., \& Taylor, S.A. (1992). Measuring Service Quality: A Reexamination and Extension. Journal of Marketing, 56, 55-68.

Cronin, J.J.Jr., \& Taylor, S.A. (1994). SERVPERF Versus SERVQUAL: Reconciling Performance-Based and Perceptions-Minus-Expectations Measurement of Service Quality. Journal of Marketing, 58, 125-131.

DeShields, O.W., Kara, A., \& Kaynak, E. (2005). Determinants of business student satisfaction and retention in higher education: applying Herzberg's two-factor theory. International Journal of Educational Management, 19(2), 128-139.

Ellsworth, J.H. (1994). Education on the Internet. Indianapolis: Sams Publishing

Flottemesch, K. (2000). Building effective interaction in distance education: A review of the literature. Educational Technology, 40(3), 46-51. 
Ford, J.B., Joseph, M., \& Joseph, B. (1999). Importance-performance analysis as a strategic tool for service marketers: the case of quality perceptions of business students in New Zealand and the USA. The Journal of Services Marketing, 13 (2), 171-186.

Franklin, K.K., \& Shemwell, D.W. (1995). Disconfirmation theory: An approach to student satisfaction assessment in Higher Education. Paper presented at the Annual Meeting of The Mid-South Educational Research Association Conference, Biloxi, November 1995. ERIC Document N. 388199.

Hamish, C. (2005): The value of student engagement for higher education quality assurance. Quality in Higher Education. 11(1), 25-36.

Harasim, L., Hiltz, S.R., Teles, L., \& Turoff, M. (1995). Learning networks: A field guide to teaching and learning online. Cambrige, MA: The MIT Press.

Hartman, K., Neuwirth, C.M., Kiesler, S., Sproull, L., Cochran, C., Palmquist, M., \& Zubrow, D. (1995). Patterns of social interaction and learning to write: Some effects of network technologies. In Berge, Z.L., \& Collins, M.P. (Eds.), Computer mediated communication and the online classroom, 2, Cresskill, $\mathrm{NJ}$ : Hampton Press, Inc, 47-78.

Hodgson, V.E. (2002). The European Union and e-learning: an examination of rhetoric, theory and practice. Journal of Computer Assisted Learning, 18, 240252.

Holsapple, C.W., \& Lee-Post, A. (2006). Defining, assessing, and promoting elearning success: An information systems perspective. Decision Sciences Journal of Innovative Education, 4(1), 67-85.

Hung, Y.H., Huang, M.L., \& Chen, K.S. (2003). Service quality evaluation by service quality performance matrix. Total Quality Management, 14(1), 79-89.

Keller, J. M. (1987). Strategies for stimulating the motivation to learn. Performance + Instruction, 26, 1-7.

Khan, B.H. (2001). A framework for web-based learning. Englewood Cliffs, New Jersey: Educational Technology Publications.

Kuh, G. D. (2003): What We're Learning about Student Engagement from NSSE: Benchmarks for Effective Educational Practices. Change, 35(2), 24-32.

Kuo, Y., \& Ye, K. (2009). The casual relationship between service quality, corporate image and adults' learning satisfaction and loyalty: A study of professional training programmes in a Taiwanese vocational institute. Total Quality Management \& Business Excellence, 20(7), 749-762.

Lawrence, J.J., \& McCollough, M.A. (2004). Implementing Total Quality Management in the classroom by means of student satisfaction guarantees. Total Quality Management, 15(2), 235-254.

Lehman, S., Kauffman, D.F., White, M.J., Horn, C.A., \& Bruning, R.H. (2001). Teacher interaction: Motivation at-risk students in web-based high school courses. Journal of Research on Computing in Education, 33(5). Retrieved from http://www.iste.org/jrte/33/5/lehman_s.html

Leonard, J., \& Guha, S. (2001). Education at the crossroads: Online teaching and students' perspectives on distance learning. Journal of Research on Technology Education, 34(1), 51-57.

Marks, R.B., Sibley, S.D., \& Arbaugh, J.B. (2005). A structural equation model of predictor for effective online learning. Journal of Management Education, 29(4), 531-563. 
Martilla, J., \& James, J. (1997). The need for implementing total quality management in education. International Journal of Educational Management, 11(3), 131135.

Martínez-Caro, E. (2011). Factors affecting effectiveness in e-learning: An analysis in production management courses. Computer Applications in Engineering Education, 19: n/a. DOI: 10.1002/cae.20337

Mayer, R.E., Heiser, J., \& Lonn, S. (2001). Cognitive constraints on multimedia learning: When presenting more material results in less understanding. Journal of Educational Psychology, 93(1), 187-198.

McGorry, S.Y. (2003). Measuring Quality in Online Programs. The Internet and Higher Education, 6, 159-177.

Mirani, R., \& King, W.R. (1994). Impacts of end-user and information center characteristics on end-user computing support. Journal of Management Information Systems, 11(1), 141-166.

Motiwalla, L., \& Tello, S. (2000). Distance Learning on the Internet: An Exploratory Study. The Internet and Higher Education, 2(4), 253-264.

Nadiri, H., Kandampully, J., \& Hussain, K. (2009). Students' perceptions of service quality in higher education. Total Quality Management, 20(5), 523-535.

Newman, A. \& Smith, M. (1999). How to create a virtual learning community. Training and Development, 53, 44-50.

Ngai, E.W.T., Poon, J.K.L., \& Chan, Y.H.C. (2007). Empirical examination of the adoption of WebCT using TAM. Computers \& Education 48, 250-267

Nunnally, J.C. (1978). Psychometric Theory. New York: McGraw-Hill.

O’Neill, M.A., \& Palmer, A. (2004). Importance-performance analysis: a useful tool for directing continuous quality improvement in higher education. Quality Assurance in Education, 12(1), 39-52.

Oliver, R.L. (1993). A conceptual model of service quality and service satisfaction: Compatible goals, different concepts. Advances in Services Marketing and Management, 2, 65-85.

Owston, R. (1997). The World Wide Web: a technology to enhance teaching and learning?. Educational Researcher, 26 (2). Retrieved from http://www.edu.yorku.ca/ rowston/article.html.

Ozkan, S., \& Koseler, R. (2009). Multi-dimensional students' evaluation of e-learning systems in the higher education context: An empirical investigation. Computers\&Education, 53, 1285-1296.

Palloff, R., \& Pratt, K. (2001). Lessons from the cyberspace classroom. San Francisco, CA: Jossey-Bass.

Papp, R. (2000). Critical success factors for distance learning. Americas Conference on Information Systems, Long Beach, CA, 2000.

Parasuraman, A., Zeithaml, V.A., \& Berry, L.L. (1985). A Conceptual Model of Service Quality and Its Implications for Future Research. Journal of Marketing, 49, 41-50.

Parasuraman, A., Zeithaml, V.A., \& Berry, L.L. (1988). SERVQUAL: A Multi Item Scale for Measuring Consumer Perception of Service Quality. Journal of Retailing, 64 (1), 12-37.

Ramsden, P. (1991). A performance indicator of teaching Quality in Higher Education: the Course Experience Questionnaire. Studies in Higher Education, $16(2), 129-150$.

Rovai, A.P. (2002). Development of an instrument to measure classroom community. The Internet and Higher Education, 5, 197-211. 
Sanders, D.W., \& Morrison-Shetlar, A.I. (2001). Students attitudes towards webenhanced instruction in an introductory Biology course. Journal of Research on Computing in Education, 33(3), 251-262.

Selim, H.M. (2007). Critical success factors for e-learning acceptance: Confirmatory factor models. Computers \& Education, 49, 396-413.

Shee, D.Y., \& Wang, Y.S. (2008). Multi-criteria evaluation of the web-based elearning system: A methodology based on learner satisfaction and its applications. Computers Education, 50(3), 894-905.

Shen, Q., Chung, J.K.H., Challlis, D., \& Cheung, R.C.T. (2007). A comparative study of student performance in traditional mode and online mode of learning. Computer Applications in Engineering Education, 15, 30-40.

Spady, W. (1970). Dropouts from higher education: An interdisciplinary review and synthesis. Interchange, 1(1): 64-85.

Stokes, S.P. (2001). Satisfaction of College Students with the Digital Learning Environment. Do Learners' Temperaments make a Difference?. Internet and Higher Education, 4(1), 31-44.

Su, B., Bonk, C.J., Magjuka, R.J., Liu, X., \& Lee, S. (2005). The importance on Interaction in web-based education: a program level case study of online MBA courses. Journal of Interactive online learning, 4 (1), 1-19.

Sun, P-C., \& Chen, H.K. (2007). The design of instructional multimedia in eLearning: A Media Richness Theory-based approach. Computers \& Education, 49, 662-676.

Swan, K. (2002). Buiding learning communities in online courses: the importance o interaction. Education Communication and Information, 2(1), 23-49.

Tinto, V. (1993). Leaving college: Rethinking the causes and cures of student attrition. Chicago: The University of Chicago Press.

Volery, T., \& Lord, D. (2000). Critical success factors in online education. The International Journal of Educational Management, 14(5), 216-223.

Vrasidas, C., \& McIsaac, S.M. (2004). Factors influencing interaction in an online course. The American Journal of Distance Education, 13(3), 22-36.

Wang, Y.S. (2003). Assessment of learner satisfaction with asynchronous electronic learning systems. Information \& Management, 4, 75-86.

Wild, R.H., \& Hope, B. (2003). DATQUAL: a prototype e-learning application to support quality management practices in service industries. Total Quality Management \& Business Excellence, 14(6), 695-713.

Yang, C.C. (2003a). Improvement actions based on the customers' satisfaction survey. Total Quality Management and Business Excellence, 14(8), 919-930.

Yang, C.C. (2003b). Establishment and applications of the integrated model of service quality measurement. Managing Service Quality, 13(4), 310-324.

Zhao, C., \& Kuh, G.D. (2004). Adding Value: Learning Communities and Student Engagement. Research in Higher Education, 45 (2), 115-138

Zhao, Y., Lei, J., Chun Lai, B.Y., \& Tan, H.S. (2005). What makes the difference? A practical analysis of research on the effectiveness of distance education. Teachers College Record, 107(8), 1836-1884. 
Figure 1. Performance-control zone of performance matrix. Source: Chen (2009)

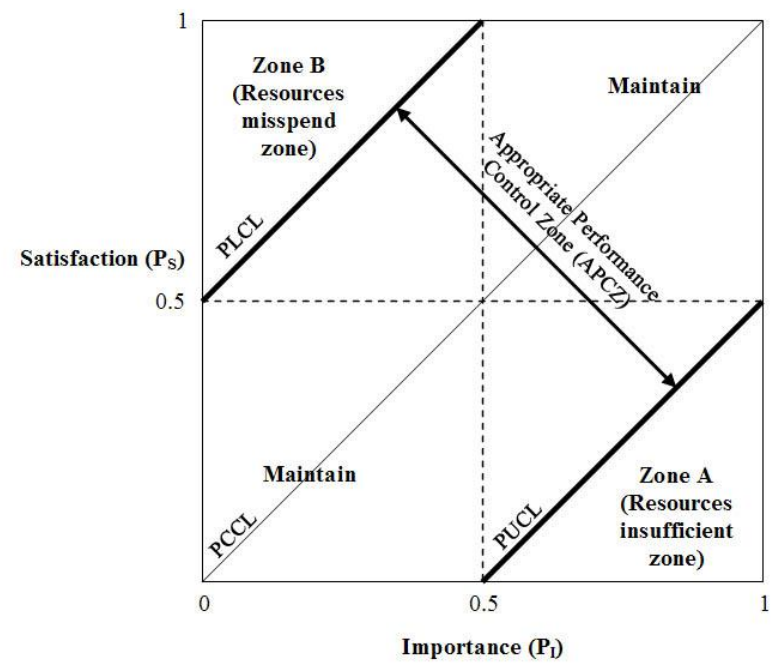

Table 1. Dimensions and items of questionnaire.

\begin{tabular}{ll}
\hline Dimensions & \\
\hline Student-Student & 1. Student interaction with other students is frequent. \\
interaction & 2. Interaction with other students is facilitated through a variety of ways. \\
& 3. I feel encouraged to interact with other students. \\
& 4. Interaction with my fellow students has allowed me to learn from them. \\
5. & Communication with other students is a positive experience. \\
Teacher-student & 6. Teacher is available to assists students. \\
interaction & 7. Teacher is active in teaching me the subject. \\
& 8. The teacher encourages student interaction with him. \\
& 9. Student interaction with faculty is frequent. \\
Content & 10. Interaction with the teacher is facilitated through a variety of ways. \\
& 11. The course contents fit my needs. \\
12. The content is up-to-date. \\
13. The course content is covered to an appropriate degree of breadth. \\
14. The course materials are placed on-line in a timely manner. \\
15. Students can interact with content through a variety of tools (e.g.
\end{tabular}


PowerPoint presentations, audios, videos, simulations, etc.).

System flexibility 16. The course allows me more flexibility in my daily activities.

and convenience

17. It was easy for me to become skilful at using the technology.

18. I have convenient access to technical assistance.

19. I can manage my "study time" effectively.

20. The course allowed me to take a class I would otherwise have to miss.

Table 2. Performance and Satisfaction Results.

\begin{tabular}{cccccc}
\hline Items & $\mu_{\mathrm{S}}$ & $\mu_{\mathrm{I}}$ & $\mathrm{P}_{\mathrm{S}}$ & $\mathrm{P}_{\mathrm{I}}$ & Index \\
\hline 1,0 & 3,7958 & 4,2282 & 0,6989 & 0,8071 & $-0,1081$ \\
2,0 & 4,2372 & 3,9099 & 0,5593 & 0,4775 & 0,0818 \\
$\mathbf{3 , 0}$ & 2,9520 & 4,2523 & 0,2380 & 0,5631 & $\mathbf{- 0 , 3 2 5 1}$ \\
4,0 & 3,7928 & 3,8138 & 0,4482 & 0,4535 & $-0,0053$ \\
5,0 & 3,8799 & 3,9069 & 0,4700 & 0,4767 & $-0,0068$ \\
6,0 & 3,9129 & 3,9730 & 0,4782 & 0,4932 & $-0,0150$ \\
7,0 & 3,8619 & 3,8709 & 0,4655 & 0,4677 & $-0,0023$ \\
$\mathbf{8 , 0}$ & 3,9309 & 3,8679 & 0,2327 & 0,7170 & $\mathbf{- 0 , 4 8 4 2}$ \\
9,0 & 3,8589 & 3,8228 & 0,4647 & 0,4557 & 0,0090 \\
$\mathbf{1 0 , 0}$ & 3,1111 & 4,2402 & 0,2778 & 0,5601 & $\mathbf{- 0 , 2 8 2 3}$ \\
11,0 & 3,7147 & 3,7748 & 0,6787 & 0,6937 & $-0,0150$ \\
12,0 & 3,9399 & 3,9550 & 0,4850 & 0,4887 & $-0,0038$ \\
13,0 & 3,8348 & 3,7988 & 0,4587 & 0,4497 & 0,0090 \\
14,0 & 3,8198 & 3,8318 & 0,4550 & 0,4580 & $-0,0030$ \\
$\mathbf{1 5 , 0}$ & 3,8006 & 3,7267 & 0,7002 & 0,4317 & $\mathbf{0 , 2 6 8 5}$ \\
16,0 & 3,8378 & 3,9489 & 0,4595 & 0,4872 & $-0,0278$ \\
17,0 & 3,9099 & 3,8649 & 0,4775 & 0,4662 & 0,0113 \\
$\mathbf{1 8 , 0}$ & 4,0811 & 3,9129 & 0,7703 & 0,4782 & $\mathbf{0 , 2 9 2 0}$ \\
$\mathbf{1 9 , 0}$ & 3,1351 & 4,3333 & 0,2838 & 0,5833 & $\mathbf{- 0 , 2 9 9 5}$ \\
20,0 & 3,8799 & 3,8318 & 0,4700 & 0,4580 & 0,0120 \\
\hline
\end{tabular}

Figure 2. Performance-control matrix. 


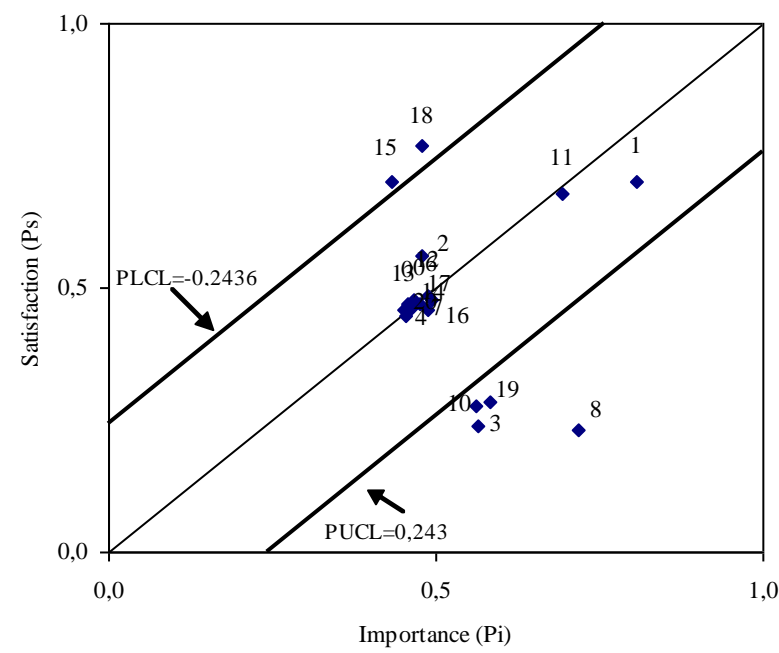

